\title{
Assessment of Major Depressive Disorders through Neuroimaging Studies and their Treatment Methods
}

\author{
Jevetha Vijayadasan $^{\mathrm{a}}$, Diksha Raghunathan ${ }^{\mathrm{a}}$, Sivakumar Rajagopal ${ }^{\mathrm{a}^{*}}$, Rahul Soangra $^{\mathrm{b}}$ \\ ${ }^{a}$ Department of Sensor and Biomedical Technology, School of Electronics Engineering, Vellore Institute of \\ Technology, Vellore, Tamil Nadu, 632014, India \\ ${ }^{\mathrm{b}}$ Department of Physical Therapy, Crean College of Health and Behavioral Sciences, Chapman University, Irvine,
} CA 92618, U.S.A

Received: August 9, 2020. Revised: January 24, 2021. Accepted: February 8, 2021. Published: February 9, 2021.

\begin{abstract}
Many mental disorders are caused due to improper regulation of the brain and depression is one such. It affects both children and adults and is very common among teenagers. There are many challenges clinicians face regarding the management of this disease. These challenges have prompted the development of various neuroimaging techniques that effectively diagnose the condition. The main techniques are Magnetic resonance imaging (MRI) and Positron emission tomography (PET) which have gained momentum over the years. Advanced MRI techniques help study certain regions of the brain such as hippocampus and amygdala. Effective treatments for depression include antidepressant medications and brain stimulation techniques. Although treatments are effective for a lot of people, there is still room for improvement. This article (1) presents background on depression, its types, symptoms and risk factors; (2) elaborates the neuroimaging techniques used and reviews the various techniques adopted over the years to study depression; and (3) discusses the treatment methods that can be practised to cure depression.
\end{abstract}

Keywords- Brain Stimulation Techniques, Depression, MDD, MRI, PET.

\section{INTRODUCTION}

$\mathrm{M}$ ost of us feels neglected or sad due to many reasons in life. It could be due to prolonged illness or sickness, financial issues, relationship troubles and many more. While some can effectively manage their feelings, others succumb to the negative emotions they feel and let it overtake them. Therefore if someone is constantly experiencing feelings of sadness for a prolonged period, they may have a major depressive disorder (MDD) [1].

Depression can be defined as an illness that involves thoughts, feelings and mood and how they adversely affect a person's health. Globally, more than 300 million [2] people are living with depression. This accounts for about $4.3 \%$ of the world's population. According to WHO's Global Health Estimates $2017,4.5 \%$ of the Indian population are dealing with depression. It is one of the most common disorders that affect the brain. It can affect anyone either indirectly or directly or through a friend [3].

There are a lot of symptoms that a depressed person can show. They comprise feelings of hopelessness or worthlessness [3] and persistent sad mood which can last up to weeks. Problems with sleep are also common. Some people get up at night [1] for something and can't fall back to sleep again whereas others could be sleeping more. One of the other reasons for depression can be low self-esteem or social anxiety. Drug or alcohol abuse [1] and certain medical conditions such as cancer or hypothyroidism can also trigger MDD. Further symptoms include lack of energy and concentration and reduction in libido. The overall depression cycle comprises of the symptoms one shows during the depression and behavioural changes that occur along with it, as shown in Fig. 1 . 


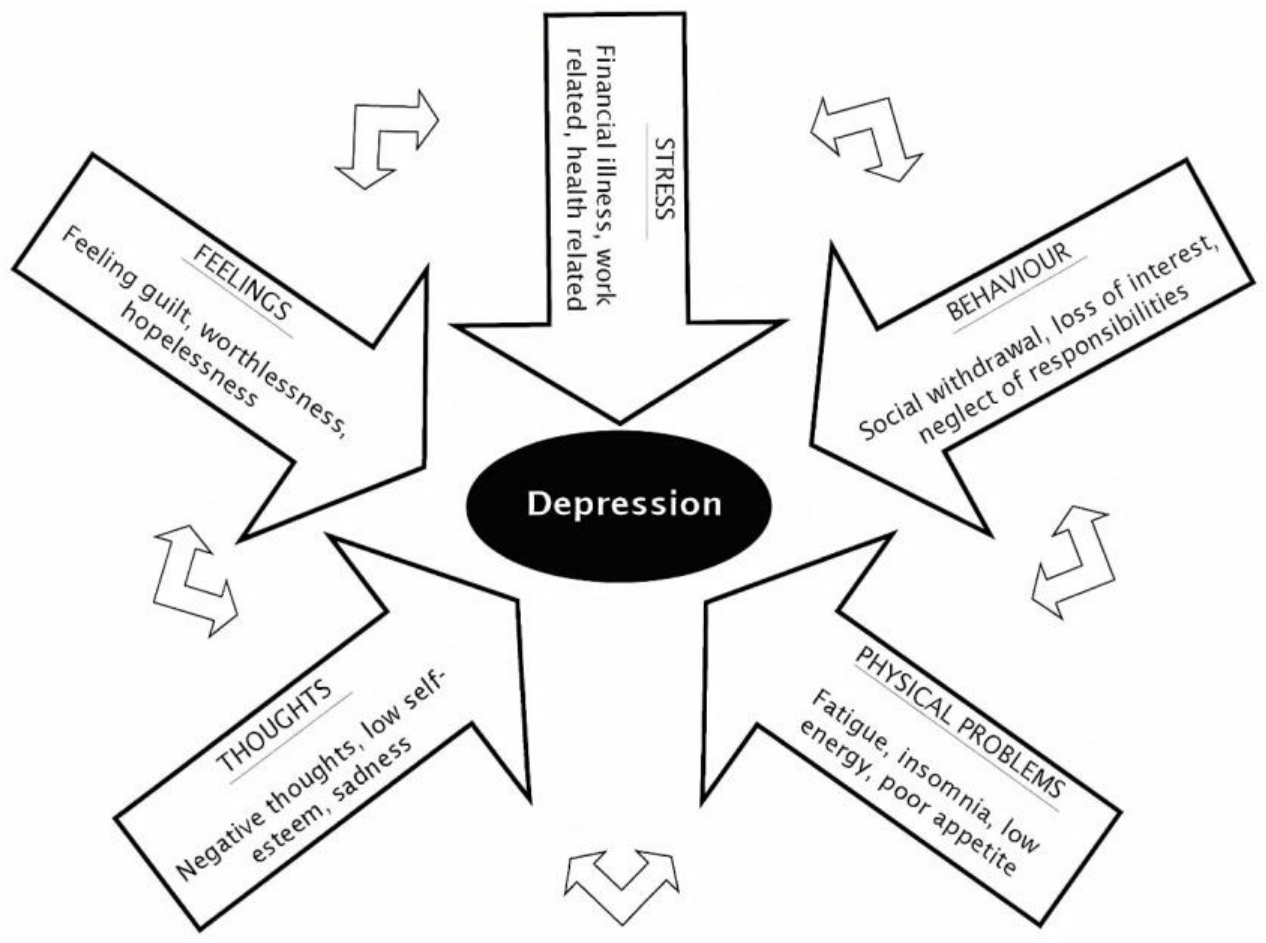

Fig. 1. The Depression cycle

Many diagnosing techniques have been adopted over the years to study depression. At first, X-rays and CT scans were used to obtain images of the brain. But with time, neuroimaging has progressed and the brain scans mostly used now are MRI and PET, which provide much clearer images of affected components of the brain. They also reveal how the brain functions in real-time. Some relevant studies can be found in [4] and [5]. By comparing these scans with the normal human brain, researchers can gain more information about the similarities and differences. The differences seen are usually in the frontal cortex of the brain or the hippocampus [6]. On rare occasions, some people could have structural issues like the presence of a cyst or tumour that could result in depression. In this review, we have summarized the imaging techniques (1999-2015) on the utilization of MRI and PET scans for the detection of depression. This helps us understand how neuroimaging has progressed over the years. But next to diagnosis comes treatment which is essential in curing the disease. We shall look further into the various treatment methods in section $\mathrm{V}$.

\section{A. Types of Depression}

The most common types of depression are melancholia, psychotic depression and antenatal and postnatal depression which can be classified under Major Depression. The person shows loss of interest and pleasure in daily activities, experiences low moods and other symptoms. One major difference is that in melancholia the person begins to move very slowly whereas in psychotic depression the person experiences hallucinations, delusions or paranoia. When the risk of depression is increased during pregnancy in women [7], it contributes to prenatal or antenatal depression. If it's after childbirth then it's the postnatal depression. Persistent Depressive Disorder is another type of depression where the person is depressed continuously for a year or longer. For both the conditions, 'dysthymia', a lower grade depressive disorder and 'chronic major depression' term is used. Medications and psychotherapy or both are specified for its treatment. Another category is Bipolar Disorder, which is also called 'manic depression'. In this, patients have episodes with extreme highs and lows. The mood fluctuations range from low to high "depressive" periods [1], [8]. During the low phase, symptoms of major depression can be witnessed. Whether its high or low phase, both need to be treated. Usually lithium, a mood stabilizer is prescribed. Another type of depression is the Premenstrual Dysphoric Disorder (PMDD), where women have depression-related symptoms at the start of their period. Seasonal Affective Disorder (SAD) is another type of depression that mostly occurs during the winter i.e. when there is less sunlight and length of day decreases. It mostly goes away by spring and summer.

\section{B. Risk Factors}

The American Psychiatric Association has divided depression risk factors into four categories: Biochemistry, Genetics, Personality characteristics and Environmental elements. The few chemicals in brain function may predispose someone to depression are they are studied in Biochemistry. Chemicals called neurotransmitters help maintain the signal flow from one neuron to another brain neuron. Examples such as serotonin and dopamine [9] usually play a role in mood regulation. Genetics suggests that depression can run in hereditary, which adds a genetic component to acquiring the disease. A twin has a 70\% chance of developing depression if the other twin has depression [9]. Research has also focussed 
on demographic variables which include gender, social status and marital status [10]. Changes in personality characteristics are often observed in teens and adolescents although it can happen at any age. According to NIMH reports, the most chronic mood changes in adults started as high anxiety that occurred when they were young, noting that increased levels of childhood anxiety could lead to a greater risk of adult depression. Apart from this, the majority of mental health specialists think that environmental factors play a significant role in transforming vulnerable people into depressed masses. The NIMH suggests that exposure to abuse, neglect and poor economic conditions can make people liable to get depressed. Occurrences such as loss of loved one, trauma, relationship troubles, financial stress and stress generally can contribute to further enhancement of depression [9].

\section{CHALLENGES AND CONTROVERSIES RELATED TO DEPRESSION}

Depressive and anxiety disorders such as common mental disorders (CMD) are regularly encountered in the primary care unit. However, the recognition of these mental disorders is very poor. Less than a third clinical case only get identified. Diagnosis is difficult in primary care due to the high rate of co-morbidity amongst diverse disorders [11].

In India, effective delivery of medications to people is still a matter of concern. There is not much availability of medicines to cater to a huge population especially in rural areas. Also, not much experience is there concerning the usage of antidepressant medicines. Not many have enough knowledge about how dangerous depression could be for a person's health. According to a study conducted by Tessa Roberts et al., [12] in rural Madhya Pradesh, $86 \%$ of screen positive adults did not seek treatment for depression. 54\% reported treatment cost and $56 \%$ reported a long distance to the medical centres as barriers. Even in the west, treatment adherence is a big hurdle in the overall treatment. So far, there has not been any convincing research from India related to improving treatment adherence [11]. One important discovery of a study was that a significant number of women [11] didn't look for help or stick to particular treatment even after additional support from the health services. This barrier needs to be investigated further.

\section{DIAGNOSIS OF DEPRESSION USING NEUROIMAGING TECHNIQUES}

\section{A. $M R I$}

One of the most difficult problems in tackling depression has been the absence of scans or lack of tests in diagnosing the condition. Scientists however have found out a way to identify MDDs easily by using radio waves and magnetic waves to look into the internal organs of the body. Scanning is done in different angles in cross-sections and slices to acquire attenuated images. These images are sent to the computer and a software programme puts these cross-sections and slices together to obtain a picture of the organ.
Three main areas where MRI reports have conveyed evident major differences in depressed brains are:

\section{Blood-brain barrier (BBB)}

BBB is the barrier between the brain tissue and the blood vessels. In recent research by $\mathrm{Dr}$ Kenneth Wengler, connections between BBB and MDD using MRI method called as IDEALS (intrinsic diffusivity encoding of arterial labelled spins) i.e., 3D MRI which gives an understanding of brain-water permeability was studied. This study showed how the water movement from blood vessels into brain tissue through BBB took place. It was done with 14 MDD patients and 14 healthy members [13]-[15]. The study elucidated that the water movement is less in patients. This confirmed the disturbances in BBB, particularly in the amygdala (responsible for emotions) and the hippocampus.

\section{Connectome}

The connectome is known as the network of complex connections. The deformities of the connectome using fMRI (shows slight changes in blood flow in the brain) were studied by Dr Goushi and his team from Chicago by observing 66 adults with MDD and 66 healthy people [14], [15]. Decreased level of excitation and inhibition in the cortex (responsible for cognitive control) and amygdala were observed in the MDD patients. Reduced levels of excitation and inhibition were noted in the dorsal lateral prefrontal cortex in MDD patients [14], [15]. Furthermore, the elevation in the amygdala was observed which contributed to anxiety and negative moods. Further research on defects in connectome can help scientists identify related defects in the brain.

\section{Machine learning algorithm}

A different study was done, where the brain patterns in depressed patients were identified. The occurrence of such similar patterns was searched in other patients to see if they were suffering from depression too. Many brain regions are involved in the network identified in depressed people. It can involve the four lobes of the brain namely, the frontal, parietal, temporal and occipital lobes as shown in Fig. 2 [16]. Machine learning and artificial learning analysis were done on the MRI data of 23 adults with MDD and 20 healthy patients [17]. This works by recognizing the patterns and learning from them to make new assumptions about new data sets.

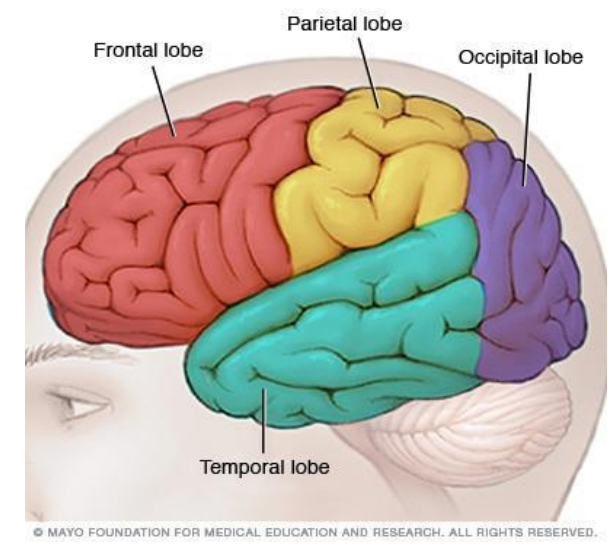

Fig. 2. Lobes of the cerebral cortex 
Variations in grey and white matter density were found in patients with depression and are shown in Fig. 3 [17]. These enlarge from prefrontal to parietal lobes and include occipital and cerebellar regions. These same patterns were matched with other people who were also suffering from depression. The same pattern was also used in individuals with different ethnicity as people from different ethnicity could demonstrate different neural responses. It was observed that the same pattern of regions was found to underlie in depressed individuals, making it the true biological marker of depression [17].

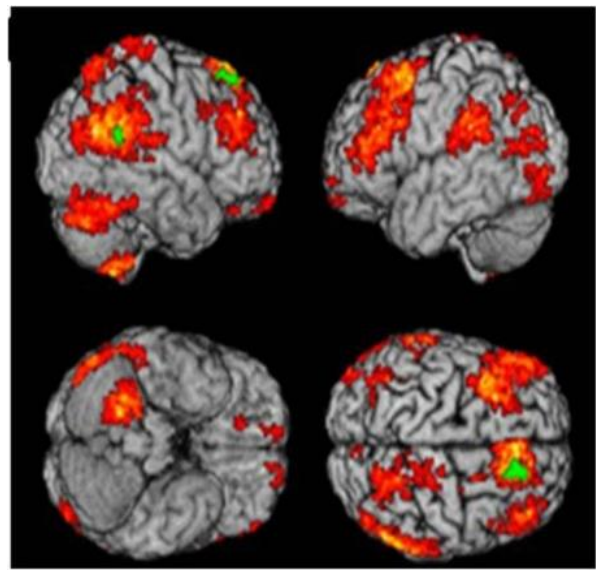

Fig. 3. Grey matter patterns in depression.

\section{B. PET}

PET is different from other imaging procedures as it is based on the molecular processes that occur in the living organisms. The positron-emitting nuclide, usually short-lived is used in PET imaging. The organ of interest is scanned after injection. PET imaging is majorly used for studying the brain, the neuro molecular processes in humans and as well as in animals. Comparison of the brain with depression and normal brain can be done with PET scan [18]. As shown in Fig. 4 [19], an increase in green and blue areas along with a decrease in yellow and white colours show reduced brain functioning because of depression [18].

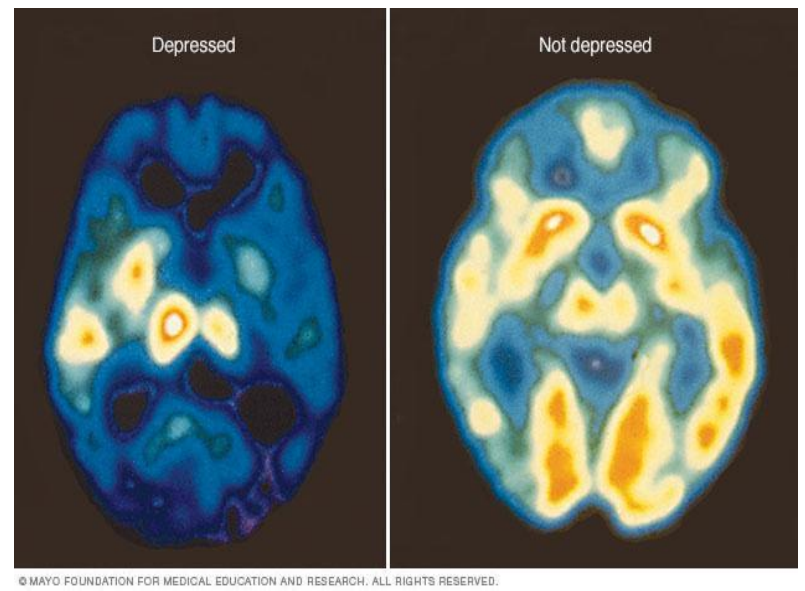

Fig. 4. PET image of depressed vs normal brain
A PET study was done on 134 participants ages $18-75$ by a team from the Research imaging centre in Toronto. The scan was done on 3 grey matter regions of the brain consisting of the insula, prefrontal cortex and anterior cingulate cortex in addition to 12 sub-regions [20], [21]. The study focused on neuro progression and microglial activation. Neuroprogression can be measured by translocator protein total distribution volume (TSPO V). The study included 3 groups: 25 patients with untreated depression for 10 years or more, 25 patients with less than 10 years of depression and 30 healthy people [20]. Greater TSPO V levels (29-33\% higher) were observed in all the three regions of the brain for individuals with longer and untreated depression compared to those who had shorter duration with no treatment [20], [21]. This implied that chronically advanced MDD patients and patients with a long period of no treatment had very high microglial activation.

\section{MRI AND PET IMAGING METHODS ADOPTED OVER THE YEARS}

MRI and PET scans have played a crucial role in understanding the pathogenesis of MDD in the last three decades. Many researchers performed PET study on serotonin receptors to identify the differences in brain patterns between a patient and normal person. Serotonin helps regulate mood and low levels of the chemical are said to be associated with depression. Subsequent research has focused on MRI scans which captured the activity of the brain in both active and resting state. Although these approaches help researchers identify and locate affected parts of the brain, none of them has reached the level of accuracy to define the "neural signature" of MDD. More recently, machine learning models have been applied to fMRI data to better understand brain connectivity and networks.

\section{TREATMENT METHODS}

According to WHO, less than $50 \%$ of the depressed patients receive treatment. Depression can have dangerous long term consequences when left untreated. Therefore it is important to treat depression in the early stages to prevent functional and morphological abnormalities. Treatment measures such as lifestyle changes are easy for an individual with fewer symptoms to incorporate, however in severe cases, decision must be made whether the patient needs to be hospitalised or treated in Outpatient department (OPD). Major treatment methods were reviewed in this study and are discussed in detail below:

\section{A. Lifestyle Changes}

Regular exercise is the best medication. Exercise increases serotonin, endorphins etc., which act as antidepressants. 30 minutes of the daily walk can create a huge difference and 3060 minutes [41] of aerobic exercises can be done for maximum results. 
Table I. Review of MRI and PET neuroimaging techniques (1999-2015)

\begin{tabular}{|c|c|c|c|c|c|c|}
\hline S.NO & TITLE & AUTHOR & PROCEDURE & RESULT & LIMITATIONS & SCOPE \\
\hline 1 & $\begin{array}{l}\text { PET study on 5- } \\
\mathrm{HT}_{2} \text { receptors in } \\
\text { depression }\end{array}$ & $\begin{array}{l}\text { Jeffrey } \text { Meyer } \\
\text { et al., } 1999 \\
\text { [22]. }\end{array}$ & $\begin{array}{l}14 \text { patients and } 19 \\
\text { controls were } \\
\text { assessed on the } \\
\text { receptor binding } \\
\text { potential }\end{array}$ & $\begin{array}{lr}\text { The } & 5-\mathrm{HT}_{2} \\
\text { receptor binding } \\
\text { potential } \quad \text { was } \\
\text { affected by age, } \\
\text { whereas } \\
\text { depression didn't }\end{array}$ & $\begin{array}{l}\text { Not aware of } \\
\text { voxel analysis for } \\
\text { obtaining the } \\
\text { images r of } \\
\text { receptor binding } \\
\text { potential }\end{array}$ & $\begin{array}{lr}\text { Voxel by } & \text { voxel } \\
\text { analysis } & \text { is } \\
\text { available } & \text { for } \\
\text { obtaining images } \\
\text { and can be used }\end{array}$ \\
\hline 2 & $\begin{array}{l}\text { PET study on } \\
\text { serotonin2 } \\
\text { receptor binding } \\
\text { in depressive } \\
\text { patients } \\
\text { following } \\
\text { treatment }\end{array}$ & $\begin{array}{l}\text { Lakshmi } \\
\text { Yatham et al., } \\
1999 \text { [23]. }\end{array}$ & 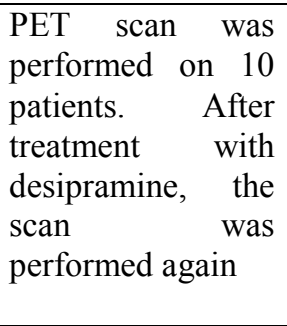 & $\begin{array}{l}\text { There was a } \\
\text { decrease in } 5-\mathrm{HT}_{2} \\
\text { binding potential } \\
\text { in depressive } \\
\text { patients }\end{array}$ & $\begin{array}{l}\text { It is not known } \\
\text { whether changes } \\
\text { in the receptor } \\
\text { was due to signs } \\
\text { of improvement } \\
\text { or an unrelated } \\
\text { effect of } \\
\text { desipramine }\end{array}$ & $\mathrm{n} / \mathrm{a}$ \\
\hline 3 & $\begin{array}{l}\text { PET study on } \\
\text { serotonin1A } \\
\text { receptor binding } \\
\text { in depressive } \\
\text { patients and it's } \\
\text { the treatment }\end{array}$ & 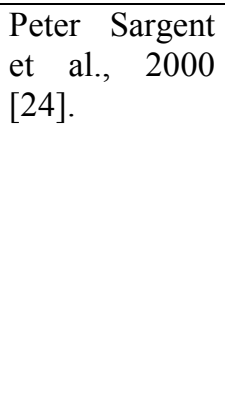 & $\begin{array}{lr}\text { PET scans } & \text { were } \\
\text { done on } & 25 \\
\text { medicated } & \text { and } \\
\text { unmedicated } & \\
\text { MDD patients } \\
\text { along } r \text { with } \\
\text { serotonin reuptake } \\
\text { treatment }\end{array}$ & $\begin{array}{l}\text { The binding } \\
\text { potential values } \\
\text { of the receptor } \\
\text { was found to be } \\
\text { decreased in } \\
\text { various brain } \\
\text { regions in MDD } \\
\text { patients compared } \\
\text { to healthy } \\
\text { volunteers }\end{array}$ & $\begin{array}{l}\text { The possibility of } \\
\text { decrease in bp } \\
\text { values for the } \\
\text { receptor is not } \\
\text { mentioned }\end{array}$ & $\begin{array}{l}\text { More study can } \\
\text { show whether the } \\
\text { decrease in bp is } \\
\text { specific in } \\
\text { depressive patients } \\
\text { or not }\end{array}$ \\
\hline 4 & $\begin{array}{l}\text { PET study on } \\
\text { serotonin } \\
\text { receptors in } \\
\text { MDD patients }\end{array}$ & $\begin{array}{l}\text { Lakshmi } \\
\text { Yatham et al., } \\
2000[25] .\end{array}$ & $\begin{array}{l}\text { PET scanning with } \\
{\left[{ }^{18} \mathrm{~F}\right] \text { Setoperone }} \\
\text { was performed on } \\
\text { healthy controls } \\
\text { and MDD patients }\end{array}$ & $\begin{array}{l}\text { It was noted that } \\
\text { in both controls } \\
\text { and patients there } \\
\text { was a negative } \\
\text { correlation in the } \\
\text { binding potential } \\
\text { of the 5-HT } 2 \\
\text { receptor and it } \\
\text { significantly } \\
\text { decreased in } \\
\text { MDD patients }\end{array}$ & $\begin{array}{l}\text { The difference in } \\
\text { cerebral } \\
\text { radioactivity } \\
\text { between controls } \\
\text { and patients } \\
\text { affects the } \\
\text { estimate of the } \\
\text { receptor }\end{array}$ & $\mathrm{n} / \mathrm{a}$ \\
\hline 5 & $\begin{array}{l}\text { Challenges in } \\
\text { mood in patients } \\
\text { with remitted } \\
\text { MDD }\end{array}$ & $\begin{array}{l}\text { Mario Liotti et } \\
\text { al., } 2002 \text { [26]. }\end{array}$ & $\begin{array}{l}\text { The changes in } \\
\text { blood flow were } \\
\text { examined using } \\
\text { PET }\end{array}$ & $\begin{array}{l}\text { It was noted that } \\
\text { in depressed } \\
\text { groups, the } \\
\text { regional cerebral } \\
\text { flow was } \\
\text { decreased in the } \\
\text { cortex while the } \\
\text { healthy group } \\
\text { didn't show any } \\
\text { signs }\end{array}$ & $\begin{array}{l}\text { It is not known } \\
\text { whether the } \\
\text { changes show a } \\
\text { marker of } \\
\text { vulnerability or } \\
\text { any changes in } \\
\text { brain function } \\
\text { due to the disease }\end{array}$ & $\begin{array}{l}\text { Long } r \text { term } \\
\text { treatment influence } \\
\text { on unipolar } \\
\text { depressed patients } \\
\text { should be studied } \\
\text { further }\end{array}$ \\
\hline 6 & $\begin{array}{l}\text { Pathophysiology } \\
\text { of depression }\end{array}$ & $\begin{array}{l}\text { Bondy } \\
\text { Brigitta, }\end{array}$ & $\begin{array}{lr}\text { Reviews } & \text { the } \\
\text { different } & \text { imaging }\end{array}$ & $\begin{array}{l}\text { The increased } \\
\text { volume of the }\end{array}$ & $\mathrm{n} / \mathrm{a}$ & $\begin{array}{l}\text { Finding out the } \\
\text { causes of treatment }\end{array}$ \\
\hline
\end{tabular}




\begin{tabular}{|c|c|c|c|c|c|c|}
\hline & & $2002[27]$. & $\begin{array}{l}\text { technique } \\
\text { including PET and } \\
\text { MRI }\end{array}$ & $\begin{array}{l}\text { brain ventricles } \\
\text { was analyzed }\end{array}$ & & $\begin{array}{l}\text { resistive } \\
\text { depression }\end{array}$ \\
\hline 7 & $\begin{array}{l}\text { PET study in } \\
\text { MDD patients } \\
\text { with and without } \\
\text { anger attacks }\end{array}$ & $\begin{array}{l}\text { Darin } \\
\text { Dougherty et } \\
\text { al., } 2004 \text { [28]. }\end{array}$ & $\begin{array}{l}30 \text { participants } \\
\text { were divided into } \\
3 \text { groups. Voxel- } \\
\text { based methods } \\
\text { were used to } \\
\text { analyse blow flow } \\
\text { changes within the } \\
\text { groups. }\end{array}$ & $\begin{array}{l}\text { When anger was } \\
\text { induced in } \\
\text { patients with } \\
\text { MDD+A, there } \\
\text { was increased } \\
\text { blood flow in the } \\
\text { left cortex. No } \\
\text { changes were } \\
\text { observed in } \\
\text { MDD-A patients }\end{array}$ & $\begin{array}{l}\text { The study does } \\
\text { not access } \\
\text { differences in sex } \\
\text { when anger was } \\
\text { introduced }\end{array}$ & MRI could be used \\
\hline 8 & $\begin{array}{l}\text { PET study on } \\
\text { serotonin1A } 2 \\
\text { receptor binding } \\
\text { in recovered } \\
\text { depressive } \\
\text { people }\end{array}$ & $\begin{array}{l}\begin{array}{l}\text { Z. Bhagwagar } \\
\text { et } \\
2004 \text { [29]. }\end{array} \\
\end{array}$ & $\begin{array}{l}14 \text { males who had } \\
\text { faced depression } \\
\text { previously were } \\
\text { deployed for the } \\
\text { study along with } \\
18 \text { healthy control } \\
\text { males. PET scan } \\
\text { was performed } \\
\text { with 5-HT } 1 \mathrm{~A} \\
\text { receptor }\end{array}$ & $\begin{array}{l}\text { The binding } \\
\text { potential of the } \\
\text { receptor } \\
\text { found to was } \\
\text { decreased be } \\
\text { patients }\end{array}$ & $\begin{array}{l}\text { The present data } \\
\text { wasn't enough to } \\
\text { distinguish } \\
\text { between these } \\
\text { possibilities }\end{array}$ & $\begin{array}{l}\text { We need further } \\
\text { studies to } \\
\text { determine how } \\
\text { there is a reduction } \\
\text { in this receptor }\end{array}$ \\
\hline 9 & $\begin{array}{l}\text { Neural response } \\
\text { to unhappy faces } \\
\text { in major } \\
\text { depression }\end{array}$ & $\begin{array}{l}\text { Cynthia H. Y } \\
\text { et al., } 2004 \\
{[30] .}\end{array}$ & $\begin{array}{l}\text { fMRI } \\
\text { performed twice in } \\
8 \text { weeks on } 2 \\
\text { groups. The facial } \\
\text { stimulus } \\
\text { morphed was } \\
\text { determine to } \\
\text { intensity } \\
\text { sadness. }\end{array}$ & $\begin{array}{l}\text { The depressed } \\
\text { patients showed } \\
\text { decreased } \\
\text { activation } \\
\text { capacity after } \\
\text { antidepressant } \\
\text { treatment }\end{array}$ & $\mathrm{n} / \mathrm{a}$ & $\begin{array}{l}\text { Improvement in } \\
\text { functioning also } \\
\text { indicates fMRI as } \\
\text { a useful tool for } \\
\text { antidepressant } \\
\text { treatment }\end{array}$ \\
\hline 10 & $\begin{array}{l}\text { PET responses in } \\
\text { patients with } \\
\text { MDD }\end{array}$ & $\begin{array}{l}\text { Maria } \\
\text { Oquendo et } \\
\text { al., } 2005[31] .\end{array}$ & $\begin{array}{l}\text { PET studies were } \\
\text { done for about } 2 \\
\text { months in female } \\
\text { patients. MDD } \\
\text { subjects with and } \\
\text { without borderline } \\
\text { personality } \\
\text { disorder were } \\
\text { compared. }\end{array}$ & $\begin{array}{l}\text { Lower rCMRglu } \\
\text { was found in right } \\
\text { regions of the } \\
\text { brain for MDD } \\
\text { with BPD and no } \\
\text { differences were } \\
\text { noted for MDD } \\
\text { without BPD }\end{array}$ & $\begin{array}{lr}\text { Only } & \text { female } \\
\text { subjects } & \text { were } \\
\text { studied } & \end{array}$ & $\begin{array}{l}\text { Data needs to be } \\
\text { generalized, it can } \\
\text { be done with } \\
\text { subjects of both } \\
\text { genders }\end{array}$ \\
\hline 11 & $\begin{array}{ll}\text { How } & \text { sleep } \\
\text { affects } & \\
\text { depression } & \end{array}$ & $\begin{array}{l}\text { Michael } \\
\text { Thase, } 2006 \\
{[32] .}\end{array}$ & $\begin{array}{l}\text { Reviews the } \\
\text { relationship } \\
\text { between sleep and } \\
\text { depression. } \\
\text { Treatment } \\
\text { procedure using } \\
\text { benzodiazepine } \\
\text { and GABA } \text { A }_{\mathrm{A}} \text { is } \\
\text { suggested }\end{array}$ & $\mathrm{n} / \mathrm{a}$ & $\begin{array}{l}\text { Focuses only on } \\
\text { sleep } \\
\text { disturbances as a } \\
\text { major aspect for } \\
\text { MDD }\end{array}$ & $\begin{array}{l}\text { Can look into other } \\
\text { factors like fatigue } \\
\text { and poor appetite }\end{array}$ \\
\hline 12 & $\begin{array}{l}\text { Variations found } \\
\text { in the brain } \\
\text { regions due to } \\
\text { depression. }\end{array}$ & $\begin{array}{ll}\text { Thomas } & \text { Frodl } \\
\text { et al., } 2008 \\
\text { [33]. }\end{array}$ & $\begin{array}{l}\text { The study is } \\
\text { designed for } 3 \\
\text { years } \\
\text { compares and } \\
\text { depressive patients } \\
\text { and } 30 \text { controls } \\
\text { using Voxel-based } \\
\text { morphometry } \\
(\mathrm{VBM})\end{array}$ & $\begin{array}{l}\text { There was a } \\
\text { decrease in the } \\
\text { density of grey } \\
\text { matter in patients } \\
\text { when compared } \\
\text { to controls }\end{array}$ & $\begin{array}{l}\text { Samples were } \\
\text { insufficient to } \\
\text { assess all factors } \\
\text { for treatment }\end{array}$ & $\begin{array}{l}\text { Larger samples are } \\
\text { needed to assess } \\
\text { this }\end{array}$ \\
\hline
\end{tabular}




\begin{tabular}{|c|c|c|c|c|c|c|}
\hline 13 & $\begin{array}{lr}\text { Coronary } & \text { flow } \\
\text { detection } & \text { using } \\
\text { PET } & \end{array}$ & $\begin{array}{l}\text { Viola } \\
\text { Vaccarino et } \\
\text { al., 2009 [34]. }\end{array}$ & 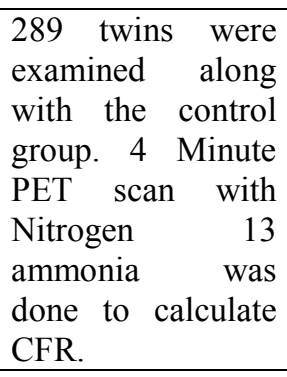 & $\begin{array}{l}\text { MDD is not } \\
\text { related to any } \\
\text { myocardial } \\
\text { perfusion defects }\end{array}$ & $\begin{array}{l}\text { The data was } \\
\text { collected and } \\
\text { reconstructed } \\
\text { without error } \\
\text { correction }\end{array}$ & $\begin{array}{l}\text { The data could be } \\
\text { used after error } \\
\text { correction }\end{array}$ \\
\hline 14 & $\begin{array}{l}\text { Neuroimaging } \\
\text { studies on MDD }\end{array}$ & $\begin{array}{l}\text { Matthew } \\
\text { Kempton et } \\
\text { al., 2011 [35]. }\end{array}$ & $\begin{array}{lr}\text { Uses } & \text { meta- } \\
\text { analysis } & \text { to } \\
\text { investigate } & \text { major } \\
\text { brain changes } \\
\text { In 3 different } \\
\text { phases }\end{array}$ & $\begin{array}{l}\text { Found that there } \\
\text { was increased } \\
\text { CSF volume in } \\
\text { MDD patients } \\
\text { and increased } \\
\text { white matter in } \\
\text { BD patients } \\
\text { compared to } \\
\text { healthy controls }\end{array}$ & $\begin{array}{l}\text { Unclear whether } \\
\text { there are common } \\
\text { irregularities } \\
\text { between MDD } \\
\text { and BD }\end{array}$ & $\begin{array}{l}\text { These } \\
\text { abnormalities } \\
\text { could be risk } \\
\text { factors for } \\
\text { amplifying MDD }\end{array}$ \\
\hline 15 & $\begin{array}{lr}\text { MRI } & \text { study } \\
\text { MDD } & \text { patients } \\
\text { and } & \text { their } \\
\text { treatment } & \end{array}$ & $\begin{array}{l}\text { Li Wang et } \\
\text { al., } 2012 \text { [36]. }\end{array}$ & $\begin{array}{l}\text { fMRI was done in } \\
\text { patients with } \\
\text { MDD to measure } \\
\text { brain activity } \\
\text { spontaneously }\end{array}$ & $\begin{array}{l}\text { Patients with } \\
\text { MDD showed the } \\
\text { increased } \\
\text { amplitude of low- } \\
\text { frequency } \\
\text { fluctuations } \\
\text { (ALFF) in the } \\
\text { right region and } \\
\text { decreased ALFF } \\
\text { in the left region } \\
\text { of the brain } \\
\text { compared to } \\
\text { healthy controls }\end{array}$ & $\begin{array}{l}\text { Couldn't } \\
\text { eliminate } \\
\text { physiological } \\
\text { noises like } \\
\text { fluctuations and } \\
\text { lacked correlation } \\
\text { between the } \\
\text { regions of the } \\
\text { brain }\end{array}$ & $\begin{array}{l}\text { The higher } \\
\text { sampling rate can } \\
\text { be used. The } \\
\text { alterations in the } \\
\text { brain could } \\
\text { contribute to } \\
\text { further studies on } \\
\text { imbalances related } \\
\text { to MDD in fMRI } \\
\text { reports }\end{array}$ \\
\hline 16 & $\begin{array}{l}\text { A meta-analysis } \\
\text { of states of } \\
\text { depression }\end{array}$ & $\begin{array}{l}\text { Julia Graham } \\
\text { et al., } 2013 \\
\text { [37]. }\end{array}$ & $\begin{array}{l}2 \text { meta-analysis } \\
\text { methods namely } \\
\text { ALE and Gaussian } \\
\text { process regression } \\
\text { (GPR) were used } \\
\text { to compare data }\end{array}$ & $\begin{array}{l}\text { Frontal areas } \\
\text { were noted to be } \\
\text { treatment } \\
\text { sensitive }\end{array}$ & $\begin{array}{l}\text { With more data, } \\
\text { there is a risk of } \\
\text { clustering of } \\
\text { heterogeneous } \\
\text { pools }\end{array}$ & $\begin{array}{l}\text { More research can } \\
\text { be done on GPR } \\
\text { and how it models } \\
\text { heterogeneity }\end{array}$ \\
\hline 17 & $\begin{array}{l}\text { A voxel-based } \\
\text { meta-analysis of } \\
\text { PET studies in } \\
\text { MDD patients }\end{array}$ & $\begin{array}{l}\text { Liang Su et } \\
\text { al., } 2014 \text { [38]. }\end{array}$ & $\begin{array}{l}\text { Using a revised } \\
\text { software re like } \\
\text { Activation } \\
\text { likelihood } \\
\text { estimation (ALE), } \\
\text { a voxel-based } \\
\text { meta-analysis was } \\
\text { carried out. }\end{array}$ & $\begin{array}{l}\text { ALE showed } \\
\text { brain metabolism } \\
\text { was slightly } \\
\text { decreased in the } \\
\text { right region in } \\
\text { patients with } \\
\text { MDD. It was } \\
\text { noted that certain } \\
\text { regions like in the } \\
\text { right thalamus, } \\
\text { brain activity } \\
\text { increased }\end{array}$ & $\begin{array}{l}\text { Lack } r \text { of } \\
\text { specificity in } \\
\text { results as they } \\
\text { seem similar to } \\
\text { other diseases } \\
\text { like } \\
\text { schizophrenia and } \\
\text { BD }\end{array}$ & $\begin{array}{l}\text { In the } \\
\text { pathophysiology of } \\
\text { depression, altered } \\
\text { metabolism in } \\
\text { regions like } \\
\text { cerebellum and } \\
\text { thalamus are to } \\
\text { play an important } \\
\text { role }\end{array}$ \\
\hline 18 & $\begin{array}{l}\text { Analysis of the } \\
\text { MDD and its } \\
\text { imaging }\end{array}$ & $\begin{array}{l}\text { M. Treadway } \\
\text { and D. } \\
\text { Pizzagalli, } \\
2014 \text { [39]. }\end{array}$ & $\begin{array}{l}\text { Reviews the } \\
\text { different } \\
\text { neuroimaging } \\
\text { studies and throws } \\
\text { some light on } \\
\text { GABA studies }\end{array}$ & $\begin{array}{l}\text { Points out that } \\
\text { studies on clinical } \\
\text { imaging can } \\
\text { provide more } \\
\text { insight on circuit- } \\
\text { based analysis }\end{array}$ & $\mathrm{n} / \mathrm{a}$ & $\begin{array}{l}\text { Integration of } \\
\text { different methods } \\
\text { using circuit-based } \\
\text { analysis can } \\
\text { contribute to the } \\
\text { development of } \\
\text { various medicines }\end{array}$ \\
\hline
\end{tabular}




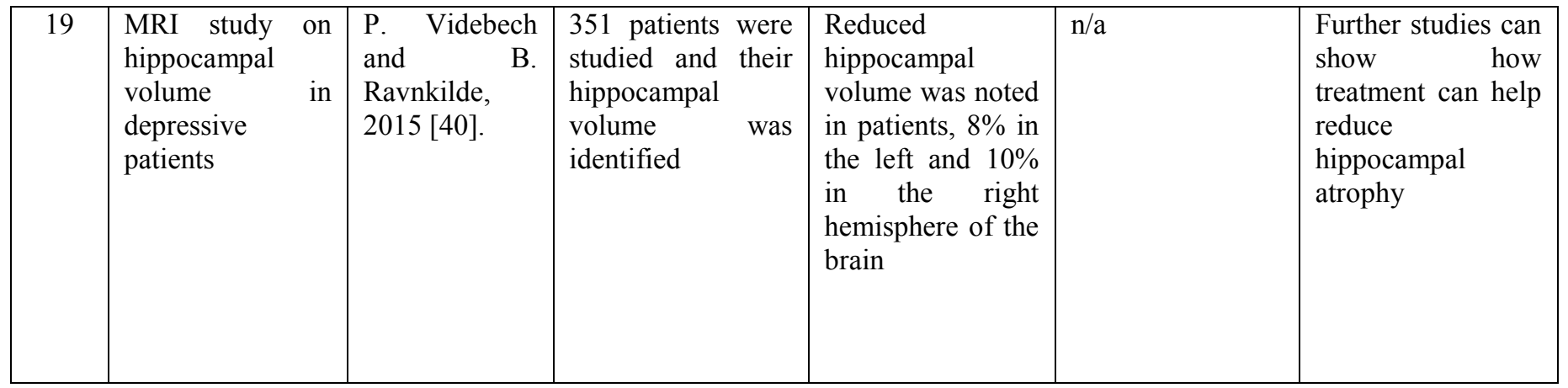

The patients must engage themselves in social activities and spend more time with their families. Apart from this, a balanced diet is important for mental and physical health [41]. This will help minimize mood swings. A proper sleep pattern should also be maintained. One should get at least 8-9hrs of sleep. Irregular sleep patterns or inadequate sleep tend to make depression worse [1].

\section{B. Psychotherapy}

Psychotherapy involves talk sessions where the patient discusses with the therapist about the underlying issue and learns the required skills to cope up. There are several therapies to treat depression and mood disorders. Commonly used therapies are Cognitive behavioural therapy(CBT), psychodynamic therapy and interpersonal therapy (IPT). CBT helps assess negative thinking patterns connected with depression and coping strategies are taught to patients so they could overcome it. This therapy is limited to 8-16 sessions [42].In psychodynamic therapy, the individual is taught to resolve the negative pattern of behaviours and negative feelings they experience which are mostly connected to their past experiences. IPT is significantly given to improve personal relationships with family and friends. It is timelimited like CBT [42]. A study conducted by Health Quality Ontario [43] showed that CBT improved symptoms, clinical response and quality of life scores in patients post-treatment. Also, patients post-treatment of IPT showed reduced MDD scores. It is estimated that the net budget of adding psychotherapy to usual care would increase around 7 folds in the next 5 years [43].

\section{Medications}

Antidepressants take 2-4 weeks to have an effect and 12 weeks to have a prominent effect. The most common medication prescribed for individuals with depression is selective serotonin reuptake inhibitors (SSRIs) [1], [41]. They consist of paroxetine and fluoxetine [41] that behave on serotonin. Serotonin and norepinephrine reuptake inhibitors (SNRIs) come second in the commonly available antidepressants. They increase the production of serotonin and norepinephrine. Venlafaxine and Desvenlafaxine are some examples of SNRIs. Second-generation antipsychotics (SGAs) treat bipolar disorder, schizophrenia, acute mania and other mental illnesses. Mirtazapine is another antidepressant that increases brain activity level by targeting specific norepinephrine and serotonin receptors. However, it's used less than newer antidepressants (SSRIs, SNRIs) because it leads to weight gain, sleepiness, dry mouth, increase in appetite [44] and sedation. Tricyclic antidepressants (TCAs) are old medications which are still used today to treat depression at its starting stage. TCAs like doxepin and amitriptyline help ease chronic pain. They are similar to SNRIs but lead to more side effects. They are used when other antidepressants don't work. It has been noted that out of 100 adult patients who took antidepressants, 40-60 people showed improved symptoms after 6-8 weeks [45].

\section{Brain Stimulation Therapies}

This includes activation or stimulation of the brain directly by giving electricity from electrodes embedded in the brain or placed on the scalp [46] or by sending magnetic fields. It's a promising treatment and is preferred over psychotherapies and medication.

\section{Electroconvulsive Therapy (ECT):}

ECT is most commonly used to treat severe depression which is treatment-resistant [46]. It involves sending short electrical impulses to the brain. It works quickly, usually starting within the first week, and is quickly responded by older people. Some common side effects related to ECT are muscle aches and headaches.

\section{Repetitive Transcranial Magnetic Stimulation (rTMS):}

This new brain invigoration technique uses a magnet to stimulate the brain. It is mostly used to treat anxiety, depression and other disorders. It can be targeted to a specific region in the brain unlike ECT [46]. Scientists believe that when a particular region is focussed, it could reduce side effects.

\section{Vagus Nerve Stimulation (VNS):}

A device is embedded under the skin and this sends electrical signals to the left vagus nerve [46]. The nerve then carries the messages to the body's major organs from the brain as shown in Fig. 5 [47]. It was initially developed to cure epilepsy [48]. Nonetheless, it was later discovered that it has favourable effects on mood [48]. Some side effects include hoarseness of voice, cough and neck pain. The individual may want to stop the function of the side effects become intolerable [46]. 


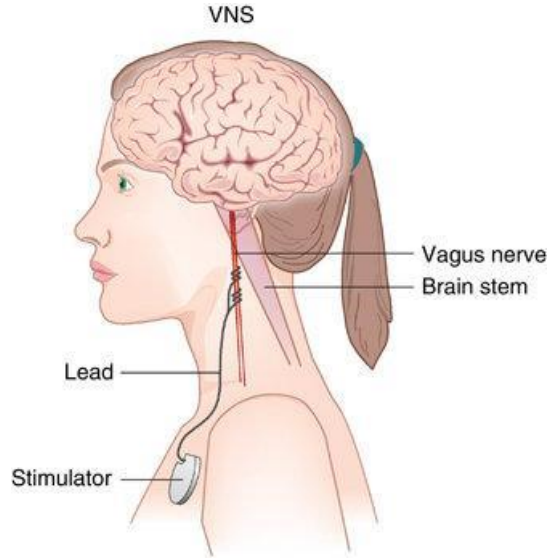

Fig. 5.Vagus Nerve Stimulation (VNS)

4. Magnetic Seizure Therapy (MST):

It's similar to both ECT and rTMS. The patient is first anaesthetized and high-frequency magnetic impulses are then given. To prevent muscle movement [46], a muscle relaxant is provided. The goal of MST is to perform like ECT while lowering its cognitive side effects.

\section{Deep Brain Stimulation (DBS):}

Initially developed as a cure for Parkinson's disease, to reduce stiffness and tremor, it is currently used to treat obsessive-compulsive disorder (OCD) [46]. DBS uses a pair of electrodes which is embedded in the brain. A generator is embedded in the chest [46] which controls the electrodes as shown in Fig. 6 [49]. Level and frequency are customized as per the individual while the stimulation is continuous. Scientists believe that it puts the brain malfunctioning area to rest so that it starts to work ordinarily. Any type of brain surgery comes with the risk. This procedure like others has side effects such as bleeding, infections and unwanted mood changes [46].

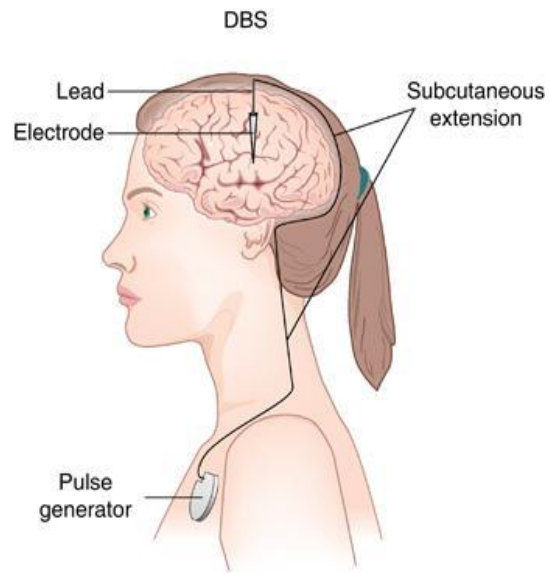

Fig. 6. Deep Brain Stimulation (DBS)

\section{E. Alternative treatments}

A good intake of vitamins and supplements with a doctor's prescription may be beneficial to overcome the symptoms of depression. Practising relaxation techniques such as doing meditation, yoga and deep breathing can help lower stress and boost feelings of joy. Acupuncture is another technique where minute needles are used on specific points on the body for treatment purposes. It rarely has side effects [50]. This method is now increasingly used as a treatment for depression and further research is ongoing.

\section{CONCLUSION}

The entire review was aimed to provide a clear understanding of depression, its symptoms, diagnosis and treatment. The focus was to summarize the existing research under sub-headings so that it's easier to locate such vast information. It is to benefit researchers, scientists, professors, students and anyone who's looking to gather an overall understanding of depression. Many techniques to diagnose and treat depression have been developed over the years. This review focussed on MRI and PET imaging techniques that help identify MDDs easily. These techniques have the potential to significantly decrease the duration of patient suffering. They help in quicker diagnosis and thereby quicker treatment, have no adverse effects on the human body, provide better image contrast and have less scanning time. MRI/PET scans detect abnormal findings that CT scans miss in more than $50 \%$ of patients scanned. Though there are several techniques to diagnose MDD, only about half of the overall cases of depression are recognized in primary care settings. Although such cases are associated with patients who have milder symptoms, this issue should not be neglected. Most of the treatment practises fall short of the existing practice guidelines. Patient outcomes are good only when the guidelines are followed. The most effective treatment option for depression is brain stimulation therapies. Of these, ECT is the oldest and most widely used procedure. More research needs to be done on other therapies to determine their safety and effectiveness in treating mental disorders.

\section{References}

[1] Michael Kerr. (2020). Major Depressive Disorder (Clinical Depression). Available: https://www.healthline.com/health/clinicaldepression\#outlook. (Accessed 30/11/2020).

[2] M. A. Bashar, A. Mehra and A. K. Aggarwal, "Integrating mental health into primary care for addressing depression in a rural population: An experience from North India," Indian J Psychiatry, vol. 61, no. 3, pp. 319-321, 2019.

[3] John M. Grohol. (2020). Introduction to Depression. Available:

https://psychcentral.com/depression/introduction-todepression/(Accessed 30/11/2020).

[4] M. Zabcikova, Z. Koudelkova, R. Jasek, U. Muzayyanah, "Examining the Efficiency of Emotiv Insight Headset by Measuring Different Stimuli," WSEAS Transactions on Applied and Theoretical Mechanics, vol. 14, no. 26, pp. 235-242, 2019.

[5] C. Patel, N. Doshi, "A Novel Approach for Patient Anatomized Authentication Scheme using Smart Card in Telecare Medical Information System," Engineering world, vol. 1, pp. 131-137, 2019.

[6] Zhang FF, Peng W, Sweeney JA, Jia ZY, Gong QY, "Brain structure alterations in depression: 
Psychoradiological evidence," CNS Neurosci Ther, vol. 24, no. 11, pp. 994-1003, 2018.

[7] WebMD. (2018). Types of Depression. Available: https://www.webmd.com/depression/guide/depressiontypes\#1 (Accessed 30/11/2020).

[8] Michael Kerr. (2019). Bipolar Disorder (Manic Depression). Available: https://www.healthline.com/health/depression/manicdepression-bipolar-disorder (Accessed 30/11/2020).

[9] American Psychiatric Association. What is Depression. Available: https://www.psychiatry.org/patientsfamilies/depression/what-is-depression (Accessed 30/11/2020)

[10] S. L. Burcusa and W. G. Lacono, "Risk for recurrence in Depression," Clin Psychol Rev, vol. 27, no. 8, pp. 959985, 2007.

[11] A. Avasthi and A. Ghosh, "Depression in primary care: challenges \& controversies," Indian J Med Res, vol. 139, no. 2, pp. 188-190, 2014.

[12] T. Roberts, R. Shidhaye, V. Patel, S. Rathod, "Health care use and treatment-seeking for depression symptoms in rural India: an exploratory cross-sectional analysis," BMC health services research, vol. 20, no. 287, 2020.

[13] Verdict Medical Devices. (2019). MRI imaging shows physical abnormalities in depressed brain. Available: https://www.medicaldevice-network.com/news/mri-fordepression/. (Accessed 30/11/2020).

[14] Catherine Paddock. (2019). New MRI Scans reveal brain features of depression. Medical News Today. Available: https://www.medicalnewstoday.com/articles/327220 (Accessed 30/11/2020).

[15] Myupchar. (2019). We can now detect depression with an MRI. Available: https://www.firstpost.com/health/wecan-now-detect-depression-with-an-mri-7744401.html. (Accessed 30/11/2020).

[16] Mayo Clinic. Brain lobes. Available: https://www.mayoclinic.org/-/media/kcms/gbs/patientconsumer/images/2013/11/15/17/44/ds00266_ds00810_i m03440_bn7_lobesthu_jpg.png. (Accessed 30/11/2020).

[17] Cynthia Fu. (2017). A brain scan to tell if you're depressed - and what treatment is needed. Available: http://theconversation.com/a-brain-scan-to-tell-if-youredepressed-and-what-treatment-is-needed-75005 (Accessed 30/11/2020).

[18] Mayo Clinic. PET scan of the brain for depression. Available: https://www.mayoclinic.org/testsprocedures/pet-scan/multimedia/-pet-scan-of-the-brainfor-depression/img-20007400 (Accessed 30/11/2020).

[19] Mayo Clinic. PET scan of the brain for depression. Available: $/ \mathrm{media} / \mathrm{kcms} / \mathrm{gbs} /$ patientconsumer/images/2017/05/15/20/19/c7_pet_depression8col.jpg. (Accessed 30/11/2020).

[20] Matt O'Connor (2018, February 27). PET imaging shows depression may be better treated in stages. Health Imaging. Available: https://www.healthimaging.com/topics/advancedvisualization/pet-imaging-shows-depression-may-bebetter-treated-stages (Accessed 30/11/2020).
[21] Anicka Slachta. (2018, February 27). PET imaging suggests major depression is a neurodegenerative disease. Radiology Business. Available: https://www.radiologybusiness.com/topics/caredelivery/pet-imaging-suggests-major-depressionneurodegenerative-disease (Accessed 30/11/2020).

[22] J. H. Meyer, et al. "Prefrontal cortex 5- $\mathrm{HT}_{2}$ receptors in depression: an $\left[{ }^{18} \mathrm{~F}\right]$ setoperone PET imaging study," The American Journal of Psychiatry, vol. 157, no. 7, pp. 1029-1034, 1999.

[23] L. N. Yatham, et al. "Decrease in Brain Serotonin 2 Receptor Binding in Patients With Major Depression Following Desipramine Treatment: A Positron Emission Tomography Study With Fluorine-18-Labeled Setoperone," Arch Gen Psychiatry, vol. 56, no. 8, pp. 705-711, 1999.

[24] P. A. Sargent, et al. "Brain serotonin1 A receptor binding measured by Positron Emission Tomography with [11C]WAY-100635: effects of depression and antidepressant treatment," Arch Gen Psychiatry, vol. 57, no. 2, pp. 174-180, 2000.

[25] L. N. Yatham, et al. "Brain Serotonin2 Receptors in Major Depression: A Positron Emission Tomography Study," Arch Gen Psychiatry, vol. 57, no. 9, pp. 850-858, 2000.

[26] M. Liotte, H. S. Mayberg, S. McGinnis, S. L. Brannan, P. Jerabek, "Unmasking Disease-Specific Cerebral Blood Flow Abnormalities: Mood Challenge in Patients with Remitted Unipolar Depression," The American Journal of Psychiatry, vol. 159, no. 11, pp. 1830-1840, 2002.

[27] B. Brigitta, "Pathophysiology of depression and mechanisms of treatment," Dialogues Clin Neurosci, vol. 4, no.1, pp. 7-20, 2002.

[28] D. D. Dougherty, et al. "Ventromedial Prefrontal Cortex and Amygdala Dysfunction During an Anger Induction Positron Emission Tomography Study in Patients With Major Depressive Disorder With Anger Attacks," Arch Gen Psychiatry, vol. 61, no. 8, pp. 795-804, 2004.

[29] Z. Bhagwagar, E. A. Rabiner, P. A. Sargent, P. M. Grasby and P. J. Cowen, "Persistent reduction in brain

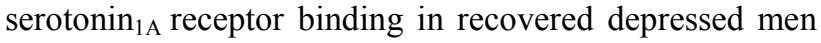
measured by positron emission tomography with [ ${ }^{11}$ C]WAY-100635," Molecular Psychiatry, vol. 9, pp. 386-392, 2004.

[30] Cynthia H. Y. Fu, et al. "Attenuation of the Neural Response to Sad Faces in Major Depression by Antidepressant Treatment: A Prospective, Event-Related Functional Magnetic Resonance Imaging Study," Arch Gen Psychiatry, vol. 61, no.9, pp. 877-889, 2004.

[31] M. A. Oquendo, et al. "Positron Emission Tomography of Regional Brain Metabolic Responses to a Serotonergic Challenge in Major Depressive Disorder with and without Borderline Personality Disorder," Neuropsychopharmacol, no. 30, pp. 1163-1172, 2005.

[32] M. E. Thase, "Depression and sleep: pathophysiology and treatment," Dialogues ClinNeurosci, vol. 8, no. 2, pp. 217-226, 2006.

[33] T. S. Frodl, et al. "Depression-related variation in brain morphology over 3 years: effects of stress?," Arch Gen Psychiatry, vol. 65, no.10, pp. 1156-1165, 2008. 
[34] V. Vaccarino, et al. "Major Depression and Coronary Flow Reserve Detected by Positron Emission Tomography," Arch Intern Med, vol. 169, no.18, pp. 1668-1676, 2009.

[35] M. J. Kempton, et al. "Structural Neuroimaging Studies in Major Depressive Disorder: Meta-analysis and Comparison with Bipolar Disorder," Arch Gen Psychiatry, vol. 68, no. 7, pp. 675-690, 2011.

[36] Li Wang, et al. "Amplitude of Low-Frequency Oscillations in First-Episode, Treatment-Naive Patients with Major Depressive Disorder: A Resting-State Functional MRI Study," PLoS ONE, vol. 7, no. 10, 2012.

[37] J. Graham, et al. "Meta-analytic evidence for neuroimaging models of depression: State or trait?," Journal of Affective Disorders, vol. 151, no. 2, pp. 423431, 2013.

[38] Liang Su, et al. "Cerebral metabolism in major depressive disorder: a voxel-based meta-analysis of positron emission tomography studies," BMC Psychiatry, vol. 14, no. 321, 2014.

[39] M. T. Treadway and D. A. Pizzagalli, "Imaging the pathophysiology of major depressive disorder - from localist models to circuit-based analysis," Biol Mood Anxiety Disord, vol. 4, no. 1, 2014.

[40] P. Videbech and B. Ravnkilde, "Hippocampal Volume and Depression: A Meta-Analysis of MRI Studies," The American Journal of Psychiatry, vol. 161, no. 11, pp. 1957-1966, 2015.

[41] Joanna Saisan, Melinda Smith and Jeanne Segal. (2019). Depression Treatment. Help Guide. Available: https://www.helpguide.org/articles/depression/depressiontreatment.htm (Accessed 30/10/2020).

[42] National Alliance on Mental Illness. (2017). Depression. Available: https://www.nami.org/Learn-More/MentalHealth-Conditions/Depression/Treatment. (Accessed 30/11/2020).

[43] Health Quality Ontario, "Psychotherapy for Major Depressive Disorder and Generalized Anxiety Disorder: A Health Technology Assessment," Ontario health technology assessment series, vol. 17, no. 15, pp. 1-167, 2017.

[44] N. Watanabe, et al. "Mirtazapine versus other antidepressive agents for depression," Cochrane Database Syst Rev, vol. 12, 2011.

[45] Brandi Koskie. (2020). Depression: Facts, Statistics, and You. Available: https://www.healthline.com/health/depression/factsstatistics-infographic. (Accessed 30/11/2020).

[46] National Institute of Mental Health. (2016). Brain Stimulation Therapies. Available: https://www.nimh.nih.gov/health/topics/brainstimulation-therapies/brain-stimulation-therapies.shtml. (Accessed 30/11/2020).

[47] M. Rosa and S. Lisanby. (2012). Somatic Treatments for Mood Disorders. Neuropsychopharmacol. Available: https://www.researchgate.net/figure/Vagus-nervestimulation-VNSDownload-Power-Point-slide-264KB_fig1_51696122. (Accessed 30/11/2020).
[48] W. C. Drevets, "Functional Neuroimaging Studies of Depression: The Anatomy of Melancholia," Annual Review of Medicine, vol. 49, no. 1, pp. 341-361, 1998.

[49] M. Rosa and S. Lisanby. (2012). Somatic Treatments for Mood Disorders. Neuropsychopharmacol. Available: https://www.researchgate.net/figure/Deep-brainstimulation-DBSDownload-Power-Point-slide-264KB fig2 51696122(Accessed 30/11/2020).

[50] K. Holland. (2018). Acupuncture for Depression: Does It Really Work? And 12 Other FAQs. Available: https://www.healthline.com/health/depression/acupunctur e-for-depression (Accessed 30/11/2020).

\section{Creative Commons Attribution License 4.0 (Attribution 4.0 International, CC BY 4.0)}

This article is published under the terms of the Creative Commons Attribution License 4.0 https://creativecommons.org/licenses/by/4.0/deed.en_US 